\title{
ORGANIC FARMING AND ESSENTIAL ELEMENTS OF LEGAL REGULATION
}

Dalia PERKUMIENĖ, Faculty of Economics and Management, Aleksandras Stulginskis university, Studentų g. 11, Akademija, LT-53361, Kauno raj., Lithuania, perkum@gmail.com (corresponding author)

Kristina LUKAUSKAITE், Management and Economics, Kaunas University of Applied Science, Gedimino g. 41 LT-44240, Kaunas, Lithuania, e-mail: kristina.lukauskaite@fc.kauko.lt

\begin{abstract}
Most of the regulations governing organic farming are mandatory, i.e., they must be observed. When farming activities are carried out in the scope of the term "ecology", very stringent requirements should be met. Any infringement in the field of organic farming is under severe punishment, and sanctions shall be applied. The article analyses the concept of organic production, organic farming principles, presents the organic farming control system, analyses the legislation set out regarding sanctions for violations committed in the field of organic farming, and introduces entities that have the right to establish and apply those sanctions.
\end{abstract}

Keywords: organic farming, legal regulation.

\section{INTRODUCTION}

Organic farming is the agricultural branch that is specifically attended on both sides - consumers and farmers who are engaged in organic farming. It should be noted that the rule of law of organic farming activities is regulated in thorough detail. It is also noteworthy that most of the rules governing organic farming are mandatory, i.e., they must be followed, and not dispositive, enabling farmers in organic production to operate more freely rather than adhere to strict standards. Organic farming is governed by the national law, European Union regulations, directives, and certain standards with binding function.

Farming activities embracing the term "ecology" shall meet very stringent requirements. Any infringement in the area of organic farming is under very strict control and sanctions shall be applied. Cases in which individuals - farmers engaged in organic production and growing the products to be sold as organic - use unauthorized synthetic materials (fertilizers) to foster growth and care of products are at variance with not only the law, but also morality. In Lithuania, the control system has been established to prevent violations in the field of organic farming, and most important, those affected products, related to information about the organic production method, used in product labeling, and advertising, were not placed in the market.

The article aims to analyse essential aspects of the legal regulation on organic farming.

The subject of the article is organic farming.

The objectives:

- Discuss the concept and principles of organic production;

- Analyse the organic farming control system;

- Analyse the legal regulation regarding sanctions applied on business entities involved in organic farming activities.

\section{METHODS}

A descriptive, legislation and case analysis methods were applied.

\section{CONCEPT OF ORGANIC PRODUCTION AND PRINCIPLES FOR ORGANIC PRODUCTION}

The term "organic" is legitimated in the EU and Lithuanian legislation. Although the terms "organic" and "ecological" have the same meaning, the word "organic" is not used in the Lithuanian language, as it is an inappropriate version of the word "organic" translation from English. The term "ecological" must be used in Lithuanian (organic food labeling, 2015).

Copyright (C) 2015 The Authors. Published by Aleksandras Stulginskis University. This is an open-access article distributed under the terms of the Creative Commons Attribution License (CC-BY 4.0), which permits unrestricted use, distribution, and reproduction in any medium, provided the original author and source are credited. 
Organic agriculture is a system for crops, livestock and fish farming that emphasizes environmental protection and the use of natural farming techniques. It is concerned not only with the end-product, but with the entire system used to produce and deliver the agricultural product ${ }^{1}$.

As already mentioned, organic farming, i.e., general objectives and principles of organic production, processing and distribution at all stages, and their control are embodied in the European Union regulations, directives, national legislation, guidance documents, standards, and so on. There are two main sets of the EU regulations as directly applicable in the Member States in the field of organic farming2: the Council Regulation (EC) No. 834/2007 of 28 June 2007 on organic production and labeling of organic products (hereinafter - the Council Regulation), and the Commission Regulation (EC) No. 889/2008 of 5 September 2008, laying down detailed rules for implementing Regulation (EC) No. $834 / 2007$ on organic production and labeling of organic products with regard to organic production labeling and control implementation (hereinafter - the Implementing Regulation). The Preamble of the Council Regulation (EC) No. 834/2007 states that the "Organic production is an overall farm management and food production system that combines best environmental practices, a high level of biodiversity, preservation of natural resources, high animal welfare standards, and a production method in line with certain consumer preferences for products produced by using natural substances and processes" ${ }^{3}$. The concept presented in Paragraph a of Article 2 of the Council Regulation (EC) No. 834/2007 defines the meaning of organic production: "organic production is a production method for use in accordance with the rules laid down in this Regulation, at all production, preparation and distribution stages" ${ }^{4}$. In the Preamble of the Council Regulation, the purpose of the organic production method is defined indicating that it "plays an important role in the society: provides for a specific market responding to a consumer demand for organic products, as well as the benefits to society, contributing to environmental protection and animal welfare and rural development." 5 The purpose and scope of application are defined in Article 1 of the Council Regulation, indicating that "this Regulation establishes an organic basis for sustainable development, whilst ensuring the effective functioning of the internal market, fair competition, consumer confidence and protection of consumer interests. It establishes common objectives and principles, which form the basis of rules of this Regulation for: a) organic production, processing and distribution at all stages and their control; b) the indications referring to organic production concerning its labeling and advertising." 6

According to Paragraph d of Article 2 of the Council Regulation, “"operator' means the natural or legal persons responsible for ensuring that the requirements of this Regulation are met within the organic business under their control."7 "Each entity engaged in organic production must first know and, without a doubt, follow the principles of organic production in the activities of organic farming, as defined in Article 4 of the Council Regulation. The latter found that organic production is based on four main principles: 1) the principle of appropriately designed and managed biological processes based on ecological systems by using internal natural resources and methods; 2) the use of external inputs limitation principle; 3 ) the use of chemically synthesized substances in strictly defined cases; 4) the application of organic production rules, taking into account sanitary status, differences in regional climatic and local conditions, stages of development and specific husbandry practices." 8

\section{Organic farming control system}

Organic farming control subjects, their concepts, and the requirements are defined in the above-mentioned Council Regulation. They are divided into three autonomous entities - the competent authority, control authority, and the inspection body. Paragraph 1 of Article 27 of the Council Regulation provides that "Member States shall set up a system of controls and designate one or more competent authorities responsible for controls in respect of the obligations established by this Regulation in conformity with Regulation (EC) No 882/2004." 9 In Paragraph 2 of the same Article, it is stated that "In addition to the conditions laid down in Regulation (EC) No 882/2004, the control system set up under this Regulation shall comprise at least the application of precautionary and control measures to be adopted by the Commission in accordance with the procedure referred to in Article 37(2). " ${ }^{10}$ The Lithuanian Supreme Administrative Court in a consistent practice has pointed out that according to the provisions laid down in the Council Regulation, the competent authority - the central authority of a Member State - shall be obliged with the organization of official controls in the field of organic production in accordance with the provisions set out in this Regulation; supervisory bodies - public administrative organization of a Member State to which the competent authority has given its full powers to carry out the inspection and certification of organic production in the area, or part of such authority; the control body - an independent private third party carrying out inspection and certification of organic production in accordance with the Council Regulation provisions. ${ }^{11}$ Paragraph $4 \mathrm{a}$ of Article 27 of the Council Regulation says that the competent authority may

\footnotetext{
${ }^{1}$ E., Morgera, C., Bullón, et al. (2012). Organic Agriculture and the Law. Rome: Food and Agriculture Organization of the United Nations, p. 5.

2 P., Craig, (2010). Lisbon Treaty. Oxford: Oxford university press.

${ }^{3}$ The Council Regulation (EC) No. 834/2007 of 28 June 2007 on organic production and organic product labeling , p. 189/1

${ }^{4}$ Ibid, Par. a, Article 2

5 Ibid, p. 189/1

${ }^{6}$ Ibid, Par. 1, Art. 1

${ }^{7}$ Ibid, Par. d, Art. 2

${ }^{8}$ Ibid, Art. 4

${ }^{9}$ Council Regulation (EC) No 834/2007 of 28 June 2007 on organic production and labelling of organic products. Par. 1,

${ }^{10}$ Ibid, Part 2, Art. 27

${ }^{11}$ Ruling by the Lithuanian Supreme Administrative Court in the administrative case No. A $^{525}-487 / 2013$ of 24 April 2013

Ruling by the Lithuanian Supreme Administrative Court in the administrative case No. $A^{602}-1174 / 2013$ of 16 September 2013
} 
commit its control competences to one or more other control authorities, or delegate control tasks to one or more control bodies. In this case, the allocated authorities are held responsible for the supervision of respective institutions. ${ }^{12}$ Under the provisions laid down in the Council Regulation, the competent authority designated in Lithuania is the Lithuanian Ministry of Agriculture. Pursuant to Paragraph 2 of Order No. 3D-11 of 9 January 2009, issued by the Lithuanian Minister of Agriculture, "On the Amendment of Order No. 375 of 28 December 2000, issued by the Minister of Agriculture, "On the Approval of Organic Farming Rules" and some invalidated orders by the Minister of Agriculture" (hereinafter - the Agricultural Rules), the PI Ekoagros was commissioned to carry out the functions of a certification body under the approved Rules of organic farming. Paragraphs 2 and 3 in Part 1 of the referred Rules indicate that these rules regulate allotment of codes for certification bodies, grant control of organic production units, set forth organic production rules, and regulate labeling of agricultural and food products produced in accordance with the EU legislation and these regulations. These rules are applied to the certification authorities, economic operators (natural and (or) legal entities) engaged in or intending to engage in organic production. ${ }^{13}$

The Agro-environmental and Organic Farming Unit at the Quality Policy Department was instructed to monitor the activities of certification bodies with regard to the exercise of organic agriculture rules. It should be noted that, in the meantime, both - the PI Ekoagros and the Agro-environmental and Organic Farming Unit at the Quality Policy Department - carry out the assigned functions. "The case-law also states that PI Ekoagros is a public administration entity executing the functions of the certification body under organic Agriculture Rules, whereas the Lithuanian Ministry of Agriculture is the subject of public administration, through its structural units, exercising control of the certification bodies." 14 The certification bodies must follow one of Europe's standards, this is LST EN ISO/IEC 17065: 2012 standard (hereinafter - European Standard), which "lays down the general requirements to be met by a third-party body, engaged in certification of products, if it is recognized as competent and reliable. In this European Standard, the term "certification body" is used for any of the bodies that certify products. The word "product" is used in the broadest sense and it includes processes and services; the word "standard" is used to incorporate other normative documents, such as specifications and technical regulations. "15 It is also noteworthy, that Paragraph 6 of Article 27 of the Council Regulation declares that competent authorities, in the case of approbation of the control body, should take into consideration the provisions of Paragraph 5 in the same Article, as well as the standard control procedure to be followed, which contains a detailed description of the control and precautions means that the institution has committed to apply on its controlled entities, together with the measures that the control body intends to apply where irregularities and (or) damage have been identified. ${ }^{16}$

\section{The legal regulation of sanctions applicable to organic production entities}

Member States operating in the field of organic production must not only create a single, clear control system, but also determine the sanctions applicable to organic production operators who do not comply with statutory requirements. "The European Union law provides basically common minimum standards; however, Member States, in their activities, are not limited to apply stricter rules, which, to their estimates, were more in line with high environmental or other mandatory targets. The aforementioned European standard specifies that the certification system used by certification bodies may embrace one or more items related with the production supervision or the supplier quality system assessment and maintenance, or both, as described in ISO / IEC Guide 53: type of testing or examination of samples taken from trade or supplier's company stock, or, testing or control of any or a particular product, new or used, also batch testing and control, project assessment." 17 It should be pointed out that there is a note at paragraph 1.2 referring to the ISO / IEC Guide 28, which highlights an advisory model for the third party in the product certification system. ${ }^{18}$ The Implementing Regulation provides that "the inspection authority or body shall carry out a physical inspection of all operators at least once a year. The inspection authority or body may take samples of unauthorised products used in organic production for investigation or examine methods of production that do not comply with the rules of organic production techniques. In addition, you can select and examine samples for detecting possible contamination by products not authorized for organic production. Such an analysis, however, is carried out only when the use of unauthorised products has been suspected." 19

One of the main misunderstandings in the process of drafting a new organic EU regulation has been the assumption that there is a problem with the "regulation" and with consumer trust. The Commission concluded that "The existing organic policy and legal framework does not provide the appropriate basis for the sustainable development of organic production in the EU" (Advisory Group on Organic Farming of 24 April 2014). With this the Commission's impact assessment asserts a need for action on the basis of assumptions that are often not sufficiently proven. Clearly a more indepth analysis of the sector would have been needed to lay the groundwork for such an ambitious project of presenting a proposal with the aim of a complete overhaul of the legislation capable of targeting the real problems facing the sector ${ }^{20}$.

\footnotetext{
${ }^{12}$ Council Regulation (EC) No 834/2007 of 28 June 2007 on organic production and labelling of organic products. Part 4, Art.27

${ }^{13}$ Organic Agricultural Rules approved by the Minister of Agriculture of Lithuania by Order No. 375 of 28 December 2000 (by the Minister of Agriculture of Lithuania on 17 April 2012). Part 1, p. 2,3

${ }^{14}$ Ruling by the Lithuanian Supreme Administrative Court in the administrative case No. A ${ }^{602}-1174 / 2013$ of 16 September 2013.

${ }^{15}$ LST EN ISO/IEC 17065:2012, 21/12/2012, 1.1 p.

${ }^{16}$ Council Regulation (EC) No 834/2007 of 28 June 2007 on organic production and labelling of organic products. Par. 6 , Art.27.

${ }^{17}$ LST EN ISO/IEC 17065:2012, 201212 21, 1.2 p.

${ }^{18}$ Ibid.

${ }^{19}$ the Commission Regulation (EC) No. 889/2008 of 5 September 2008, laying down detailed rules for implementing Regulation (EC) No. 834/2007 on organic production and labeling of organic products with regard to organic production labeling and control implementation. Par. 1,2, Art 65.

${ }^{20}$ Position on the Commission proposal for a new organic regulation. A Roadmap towards sustainable growth of the EU organic sectorUpdated version - 15 January, 2015.
} 
Paragraph 6 of Article 27 states that the competent authorities when approving a control body should take into account the standard inspection procedure to be followed, containing a detailed description of the inspection measures and precautions which the body undertakes to impose on its controlled entities, in cases of discrepancies or infringements in organic farming. ${ }^{21}$ Clause 20 of the Rules of organic agriculture declares that organic agricultural product producer and (or) the manager who are violating the Regulation (EC) No. 834/2007, Regulation (EC) No. 889/2008 or requisitions of these regulations, shall be assessed by the certification bodies as non-compliant. ${ }^{22}$ The Lithuanian Ministry of Agriculture has bound PI Ekoagros, as a competent body, to develop a system of sanctions and execute the certification of organic products. "By delegating PI Ekoagros to pursue organic certification, the Ministry of Agriculture has determined that it is the latter that may identify non-compliance and impose sanctions." "23 "The Lithuanian Supreme Administrative Court also held that the defendant public institution Ekoagros is competent enough to determine the Non-conformity assessment procedures and take measures when irregularities are detected. The Non-conformity assessment procedure confirmed by the defendant shall be regarded as an integral part of the contracts for organic production and processing activities, and shall be considered as the single condition for the issue of certification and supporting documents. " 24 "In implementation of Regulation No. 834/2007 and the Regulations' provisions resulting from the right of certifying ecological farms, in order to identify non-compliance and to impose sanctions, PI Ekoagros Director confirmed the non-compliance document, which states that if, during the inspection, unauthorized substances were found in the fields at the time of the certification procedure $<\ldots>$ the non-compliance of fifth level shall be determined followed by an applicable sanction of noncertification." ${ }^{25}$ For example, the use of unauthorized chemical substances in organic production is subject to the established sanction - non-certification of the entire economy, although the forbidden substances were found in only a small part of the farm. However, as stated by the Supreme Administrative Court of Lithuania, the harsh sanction like this "in its essence, complies with Paragraph 1 of Article 30 of the Regulation, providing for the consequences - the applicant has been deprived of the right to sell products using the organic production indications in the product labeling and advertising. <...> The panel of judges considers this strictest instrument to be in line with the objectives raised and allows controlling authorities to effectively ensure that the market would not give any way to deceptively associated products linked with organic production. It should be emphasized that organic farming is based on the proper management of biological processes based on ecological systems, by strictly limiting external inputs and chemically synthesized substances. Therefore, when unauthorised substances are found, non-certification of the entire economy fully justifies the protection of the environment, wildlife welfare, and consumer confidence in the targets to be achieved by the development of organic production." 26

\section{CONCLUSIONS}

Organic production is an overall running of economy and food production system that combines best environmental practices, a high level of biodiversity, preservation of natural resources, high animal welfare standards and a production method in line with certain consumer preferences for products produced by using natural substances and processes. Organic production is based on four main principles: 1) the principle of the appropriate design and management of biological processes based on ecological systems, by using natural resources and methods of approach; 2) the use of external inputs limitation principle; 3) the principle of strictly defined cases of the use of chemically synthesized substances; 4) the principle of organic production rules, taking account of sanitary status, differences in regional climate and local conditions, in stages of development and specific husbandry practices.

Organic farming control system of an EU Member State is essentially composed of three independent entities: the competent authority, control authority, the inspection body.

In approving a control body, the competent authority takes into account the standard inspection procedure to be followed, containing a detailed description of the inspection measures and precautions which the body undertakes to impose on its controlled entities in the case of organic farming when discrepancies and (or) damage are detected. In Lithuania, producers and (or) supervisors of ecological agricultural production, who have violated the Regulation (EC) No. 834/2007, the Regulation (EC) No. 889/2008 or regulations of the Republic of Lithuania for organic agriculture, are assessed of nonconformity by certification bodies.

\section{REFERENCES}

1. Craig, P. 2010. Lisbon Treaty. Oxford: Oxford university press. http://dx.doi.org/10.1093/acprof:oso/9780199595013.001.0001

\footnotetext{
${ }^{21}$ Council Regulation (EC) No 834/2007 of 28 June 2007 on organic production and labelling of organic products. Par. 6 , Art.27

${ }^{22}$ Organic Agricultural Rules approved by the Minister of Agriculture of Lithuania by Order No. 375 of 28 December 2000 (by the Minister of Agriculture of Lithuania on 17 April 2012). p. 20

${ }^{23}$ Ruling by the Chief Administrative Dispute Commission of 15 May 2015 in the administrative case No. 3R-185 (AG-127/04-2015); Ruling by the

Chief Administrative Dispute Commission of 3 December 2014 in the administrative case No. 3R-494 (AG-425/04-2014)

${ }^{24}$ Ruling by the Lithuanian Supreme Administrative Court of 16 September 2013 in the administrative case No. A ${ }^{602}-1174 / 2013$;

Ruling by the Lithuanian Supreme Administrative Court of 20 September 2012 in the administrative case No. A ${ }^{492}-2575 / 2012$;

Ruling by the Lithuanian Supreme Administrative Court of 22 November 2012 in the administrative case No. A ${ }^{520}-2664 / 2012$.

${ }^{25}$ Ruling by the Lithuanian Supreme Administrative Court of 16 September 2013 in the administrative case No. A ${ }^{602}-1174 / 2013$;

Ruling by the Lithuanian Supreme Administrative Court of 20September 2012 in the administrative case No. A ${ }^{492}-2575 / 2012$;

Ruling by the Lithuanian Supreme Administrative Court of 22 November 2012 in the administrative case No. $A^{520}-2664 / 2012$.

${ }^{26}$ Ruling by the Lithuanian Supreme Administrative Court of 16 September 2013 in the administrative case No. A ${ }^{602}-1174 / 2013$.
} 
2. Tarybos reglamentas (EB) Nr. 834/2007 dèl ekologinès gamybos ir ekologiškų produktų ženklinimo. (2007. 28 June. Council Regulation (EC) No. 834/2007 on organic production and labeling of organic products). (In Lithuanian)

3. Komisijos Reglamentas (EB) Nr. 889/2008 kuriuo nustatomos išsamios Tarybos reglamento (EB) NR. 834/2007 dẻl ekologinès gamybos ir ekologiškų produktų ženklinimo igyvendinimo taisyklès dèl ekologinės gamybos ženklinimo ir kontrolès. Lietuvos Respublikos individualių įmonių įstatymas. Valstybės žinios. 2003. Nr. 112-4991. (2008. 5 September. Commission Regulation (EC) No. 889/2008 laying down detailed rules for implementing Regulation (EC) NO. 834/2007 on organic production and labeling of organic products with regard to organic production and labeling of control. The Republic of Lithuania for individual companies. The Gazette. 2003 No. 112-4991.). (In Lithuanian)

4. Ekologinès žemès ūkio taisyklès patvirtintos Lietuvos Respublikos žemès ūkio ministro 2000 m. gruodžio 28 d. įsakymu Nr. 375 (Lietuvos žemès ūkio ministro $2012 \mathrm{~m}$. balandžio $17 \mathrm{~d}$.). (Organic farming rules approved by the Lithuanian Minister of Agriculture in 2000. 28 December. Order No. 375 (Lithuanian Minister of Agriculture in 2012. April 17)). (In Lithuanian)

5. Ekologiško maisto ženklinimas. (Organic food labeling. Internet access: http://vmvt.lt/lt/maisto.sauga.ir.kokybe/ekologiskas.maistas/ekologisko.maisto.zenklinimas. (accessed on 10/04/2015). (In Lithuanian)

6. Morgera, E., Bullón, C., et al. 2012. Organic Agriculture and the Law. Rome: Food and Agriculture Organization of the United Nations.

7. Position on the Commission proposal for a new organic regulation. A Roadmap towards sustainable growth of the EU organic sector. Updated version - 15 January, 2015.

8. LST EN ISO/IEC 17065:2012, 201212 21. Conformity assessment - Requirements for bodies certifying products, processes and services (ISO/IEC 17065:2012) (In Lithuanian)

9. Lietuvos vyriausiojo administracinio teismo $2013 \mathrm{~m}$. balandžio $24 \mathrm{~d}$. nutartis administracineje byloje Nr. $\mathrm{A}^{525}-487 / 2013$. (The Lithuanian Supreme Administrative Court in 2013. 24 April. Administrative case. A525-487 / 2013th). (In Lithuanian)

10. Lietuvos Vyriausiojo administracinio teismo $2013 \mathrm{~m}$. rugsejo $16 \mathrm{~d}$. nutartis administracinèje byloje Nr. $\mathrm{A}^{602}-1174 / 2013$. (Lithuanian Supreme Administrative Court in 2013. 16 September. The administrative case. A602-1174 / 2013 ${ }^{\text {th }}$ ). (In Lithuanian)

11. Lietuvos Vyriausiojo administracinio teismo $2012 \mathrm{~m}$. rugsèjo $20 \mathrm{~d}$. nutartis administracinèje byloje $\mathrm{Nr}$. $\mathrm{A}^{492}-2575 / 2012$. (Lithuanian Supreme Administrative Court in 2012. 20 September. The administrative case. A492-2575 / 2012 ${ }^{\text {th }}$. (In Lithuanian)

12. Lietuvos Vyriausiojo administracinio teismo $2012 \mathrm{~m}$. lapkričio $22 \mathrm{~d}$. nutartis administracinèje byloje Nr. $\mathrm{A}^{520}-2664 / 2012$. (The Lithuanian Supreme Administrative Court in 2012. 22 November. The administrative case. A520-2664 / 2012 ${ }^{\text {th }}$ ). (In Lithuanian)

13. Morgera, E., Bullón, C., et al. 2012. Organic Agriculture and the Law. Rome: Food and Agriculture Organization of the United Nations.

14. Vyriausiosios administracinių ginčų komisijos 2014 m. gruodžio 3 d. spendimas administracinèje byloje Nr. 3R-494 (AG-425/042014). (The Chief Administrative Disputes Commission in 2014. 3 December. decision 'in the administrative case no. 3R-494 (WH-425 / 04-2014)). (In Lithuanian)

15. Vyriausiosios administracinių ginčų komisijos 2015 m. gegužès 15 d. spendimas administracinèje byloje Nr. 3R-185 (AG-127/042015). (The Chief Administrative Disputes Commission in 2015. 15 May. Decision 'in the administrative case no. 3R-185 (WH127 / 04-2015)). (In Lithuanian)

16. Vilniaus apygardos administracinio teismo $2012 \mathrm{~m}$. spalio 8 d. sprendimas administracinejje byloje Nr. I-3326-561/2012. (The Vilnius Regional Administrative Court in 2012. 8 October. Administrative proceedings. I-3326-561 / 2012th). (In Lithuanian) 